\title{
Forest Service Budget Requests and Appropriations: What Do Analyses of Trends Reveal?
}

\section{Timothy J. Farnham}

\begin{abstract}
In spite of recent arguments that significant changes are occurring in the United States Department of Agriculture's Forest Service, to date little empirical evidence exists demonstrating that this is indeed the case and whether these presumed changes are impacting upon substantive policy outcomes. Most of the current evidence available is from studies that have inferred change by measuring attitudinal change in Forest Service employees. None to date has examined changes in quantitative indicators of agency policy efforts or outcomes.

In this article, we analyze trends in the budget requests of the Forest Service, the United States Department of Agriculture (USDA), and the Office of Management and Budget (OMB), and appropriations made by Congress, to ascertain whether priorities of these actors concerning the commodity and non-commodity programs of the National Forests have changed since the passage of the National Forest Management Act. The data reveal shifting priorities for the Forest Service, USDA, and OMB. However, although the shifts have been greater for the Forest Service than for the other two agencies, they have been significantly less than the shifts in congressional appropriations. This fact suggests that Congress is changing its view of how the Forest Service should manage its lands more quickly than the Forest Service is changing itself, and that, as some have argued, Congress has been an important external agent of change concerning the agency and its policies.
\end{abstract}

There has been much debate over the past decade concerning changes in the United States Forest Service, particularly the management practices and priorities of the agency (Brown \& Harris, 1992; McCarthy, Sabatier, \& Loomis, 1991; Tipple \& Wellman, 1991). Assessing any change that has occurred is somewhat problematic, in that objective measures often are difficult to find. Previous studies have relied mostly on data obtained through surveys of Forest Service employees and on those who work closely with the agency (Mohai, Stillman, Jakes, \& Liggett, 1992; Jones \& Mohai, 1995). In contrast, this analysis of budget requests and appropriations is intended to provide a quantitative foundation for assessing whether changes have occurred in Forest Service programs.

By studying trends in congressional appropriations over the past decade, it is possible to track changes in funding levels for specific Forest Service line items, and thus to gain insight into how much influence Congress has had in directing Forest Service actions through the budget process. In addition, the budget requests of the Forest Servicc, the United States Department of Agriculture (USDA), and the Office of Management and Budget (OMB) will be examined, to ascertain the priorities of these offices. The Forest Service requests will be of particular interest, for they will indicate any change of priorities initiated by the agency, possibly in response to external pressures. Some studies have concluded that the pressures exerted by public interest groups have played a significant role in the planning procedures of government agencies (Klay \& McElveen, 1991; Jones \& Taylor, 1995). The purpose of this stury is to illustrate quantitatively that the Forest Service has internalized these changes. 
In particular, this study will focus on changes in appropriations and requests that have occurred in commodity and non-commodity programs. Six line items within the National Forest System-Timber Sales, Recreation, Wildlife and Fish, Soils Management, Range Management, and General Administration-will be examined to detect any shifts in funding priorities.

\section{The Budget as Part of the Planning Process}

Some information about the Forest Service budget process is necessary for understanding the relevance of this study. Rather than a single event occurring once every year, the congressional appropriation of funds for the Forest Service is an integral part of the ongoing planning process that occupies the agency year-round (Sample, 1990). When perceived in this way, the important influence that appropriations levels have on the management of National Forests becomes clear. Ostensibly, the level of funding for a specific program is a key determinant of how successfully that program will be able to carry out its stated objectives. Ideally, budgeting should be integrated fully with strategic planning and program management, and together, these three stages of the overall planning process should work towards common, clearly-defined goals (Sample, 1992).

Through passage of the Forest and Rangelands Renewable Resources Planning Act of 1974 (RPA) and the National Forest Management Act of 1976 (NFMA), definite steps have been taken to establish the goals and objectives that would guide the management of the National Forests. Yet throughout the 1980s, it was evident that the budget process never was well-integrated with the planning process, and that the funds allocated to the various Forest Service programs did not always reflect the intention of either the RPA documents or the individual Forest plans (Sample, 1990). Because ultimately it controls the funding levels, Congress has considerable influence over the success of specific Forest Service programs. As V. Alaric Sample, former Director of the Forest Policy Center at the American Forestry Association (now American Forests), writes, "[o]ne of the greatest concerns facing local National Forest managers ... is that the current budget and appropriations process will derail the years of effort that have gone into National Forest planning" (Sample, 1990).

Previous studies have dealt more specifically with the lack of integration between the budget process and the planning process, and how this influences the management of the National Forests (Sample, 1990; Gremillion, McKenny, \& Pyburn, 1980; Novick, 1973). Recently, Sample (1992, p. 339) discussed how "the Forest Service is currently experimenting with measures to alleviate this situation by improving the integration between its budgetary and planning processes, both internally and in its relationship with congressional committees." This change is noteworthy; however, the time series data used in this study will not be useful in analyzing the effectiveness of such recent activities associated with the budget process. Rather, this study is concerned with trends of congressional appropriations, and how they relate to the requests for funds from the Forest Service, USDA, and OMB.

It can be argued that appropriations are not the best measure of what the Forest Service actually spends on its various programs, and therefore that such an analysis will reveal only congressional priorities and little else. Ideally, one would look at Forest Service outlays or expenditures for each of the past ten years, but the available data were not detailed enough to provide trend information necessary for a useful analysis of outlays for the various Forest Service programs, such as timber sales, recreation, and wildlife and fish. However, the line-item format in the budget requests and appropriations lends itself extremely well to such an analysis. Of course, 
appropriations are a measure of what is available to an agency, but the amount allocated to a program likely will represent what the agency ends up spending under that program. Some organizational theorists suggest that in managing public agencies, a primary goal of the managers is "budget maximization;" in other words, taking actions to effect increases in the budget for their division. O'Toole (1988), finds that budget maximization is an appropriate model for the Forest Service. Under this model, it is likely that Forest Service program managers often may find a way to spend the money that is allocated to them, for fear that if they do not their funding for the next year would be reduced accordingly.

It is important to note the problems that are raised by this behavior. A simple increase in funding certainly does not translate definitively into a significant change in the agency's programs and outputs. The money could be used in many different ways for the simple purpose of exhausting the appropriated funds. Similarly, money allocated for one program through one line item actually may be used to fund another program that falls under a different line item. This problem is a distinct possibility when working with a government agency like the Forest Service, for there are many overlapping tasks and objectives that cross the boundaries of line-item categories. An example of this problem was reported in a recent General Accounting Office (GAO) report that found a significant percentage of the Forest Service's Wilderness Management budget actually was used for other activities besides wilderness management (GAO, 1992). When land is managed for multiple uses, as is required for the Forest Service, management activities often are hard to categorize, or simply can be written off as providing benefits for a variety of programs. The in-depth Forest-byForest analysis that would be necessary to root out these inconsistencies in the use of allocated funds is beyond the scope of this study. However, with recognition of these drawbacks we proceed with our analysis of appropriations. The numbers certainly are indicative of the congressional priorities for the Forest Service, and are useful data in their representation of what money was available to the Forest Service for its various programs.

In analyzing trends in Forest Service budget requests, the assumption is made implicitly that the Forest Service wants exactly the amount of funding that it asks for. It is more likely that the Forest Service calculates political feasibility into its requests, trying to anticipate the political climate that will influence USDA and OMB requests and Congress's final appropriations. However, in examining budget requests from the Forest Service, USDA, and OMB, it is apparent that separating out true financial need from national budgetary politics is an impossible task. The political interplay of the different agencies and offices, and the effect that this interplay has on the actual budget numbers in the requests, are not readily obvious to outsiders. The reasons why the different offices made specific requests certainly have varied over the last decade, and surely each separate budget request is influenced by what had occurred in previous years, or by what was expected to occur in future years. This interaction itself would provide an interesting topic for further study. We can note here only that the trends in budget requests are likely to be influenced by a more complicated mix of factors than simply how much the different offices believe to be a fair allocation of funds.

In the following, the analysis of Forest Service budget trends is divided into two components. First, for the line items mentioned previously, trends in congressional appropriations-which represent the amount of money allocated to the Forest Service by the federal government for each of the various programs within the agency - will be analyzed to assess likely influences on Forest Service programs. The second component is a comparison of the budget requests of the Forest Service, USDA, 
and $\mathrm{OMB}$, and a brief analysis of how these requests relate to the final appropriations passed by Congress.

\section{Methods}

The data used in this analysis were taken from three different sources: the Forest Service's Budget Explanatory Notes for the Committee on Appropriations FY 1983-1994 (United States Department of Agriculture, Forest Service, 1981-1992); the Forest Service's annual Reports of the Forest Service FY 1983-1991 (United States Department of Agriculture, Forest Service, 1984-1992); and figures provided by the Forest Service's Program Development and Budget office. Numbers for congressional appropriations and OMB requests were taken from the Budget Explanatory Notes and were cross-checked with the other two sources. Forest Service and USDA requests were available only through the Forest Service Program Development and Budget office. All data have been adjusted for inflation by using the inflation multiplier given in $S B B I$ : Stocks, Bonds, Bills, and Inflation Index (Ibbotson Associates, 1992). The budget numbers are reported in constant 1992 dollars. There have been several changes in line-

\section{Figure 1}

Congressional Appropriations for the United States Forest Service (USFS)
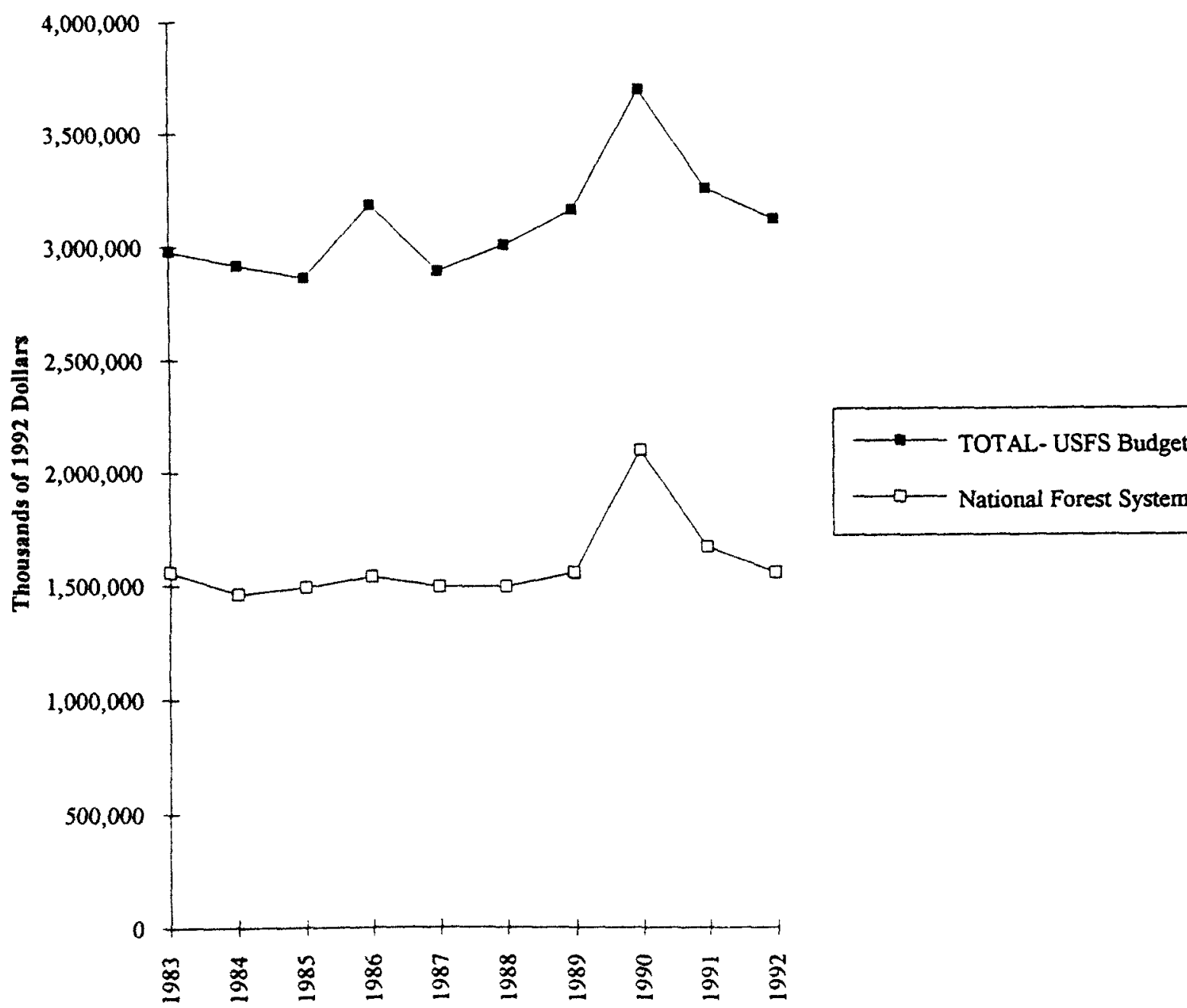

$\longrightarrow-$ National Forest Systern 
item names and contents, but in all cases the line-item titles listed for the 1992 budget were used, and appropriate combinations or disaggregations were made so that the lineitems' contents were consistent over time.

\section{Results}

Total congressional appropriations for the Forest Service have shown a slight increase since the early 1980s (Figure 1). After an initial decrease, Forest Service funding has increased from $\$ 2.9$ billion in 1985 to $\$ 3.2$ billion in 1991, finishing in 1992 at $\$ 3.1$ billion. The upward spikes in 1986 and 1990 are the results of two singular allocations: In 1986, extra funds (about $\$ 260$ million) were allocated for the Payments to States line item in order to dissolve a backlog of payments to the various states and counties; in 1990, \$500 million extra was allocated for firefighting in response to particularly destructive fires in the West. If these two events were corrected for, we would find a fairly smooth U-shaped curve indicating that a small upward trend in overall funds for the Forest Service has occurred, although the 1992 appropriations level suggests that this trend may be over.

A comparison of the different budget requests from the Forest Service, USDA, and OMB, with actual total appropriations, is shown in Figure 2. Between 1983 and 1985 , all three offices reduced their request levels-most notably the Forest Service, which decreased its request from $\$ 3.7$ billion in 1983 to $\$ 2.9$ billion in 1985 , matching congressional appropriations for that year. Starting in 1986, however, Congress began to fund the Forest Service at levels higher than any of the three requests, and continued to do so (excepting 1987) until 1992. Examination of the trends in Figure 2 indicates that budget requests tend to follow congressional appropriations. That is, when Congress sets the appropriations for the agency in one year, the agency's budget request tends to adjust to that level the following year. This pattern thus appears to suggest that, rather than agency requests having influenced congressional appropriations, congressional appropriations influence agency requests.

\section{Figure 2}

Total Budget Requests and Appropriations for the Forest Service

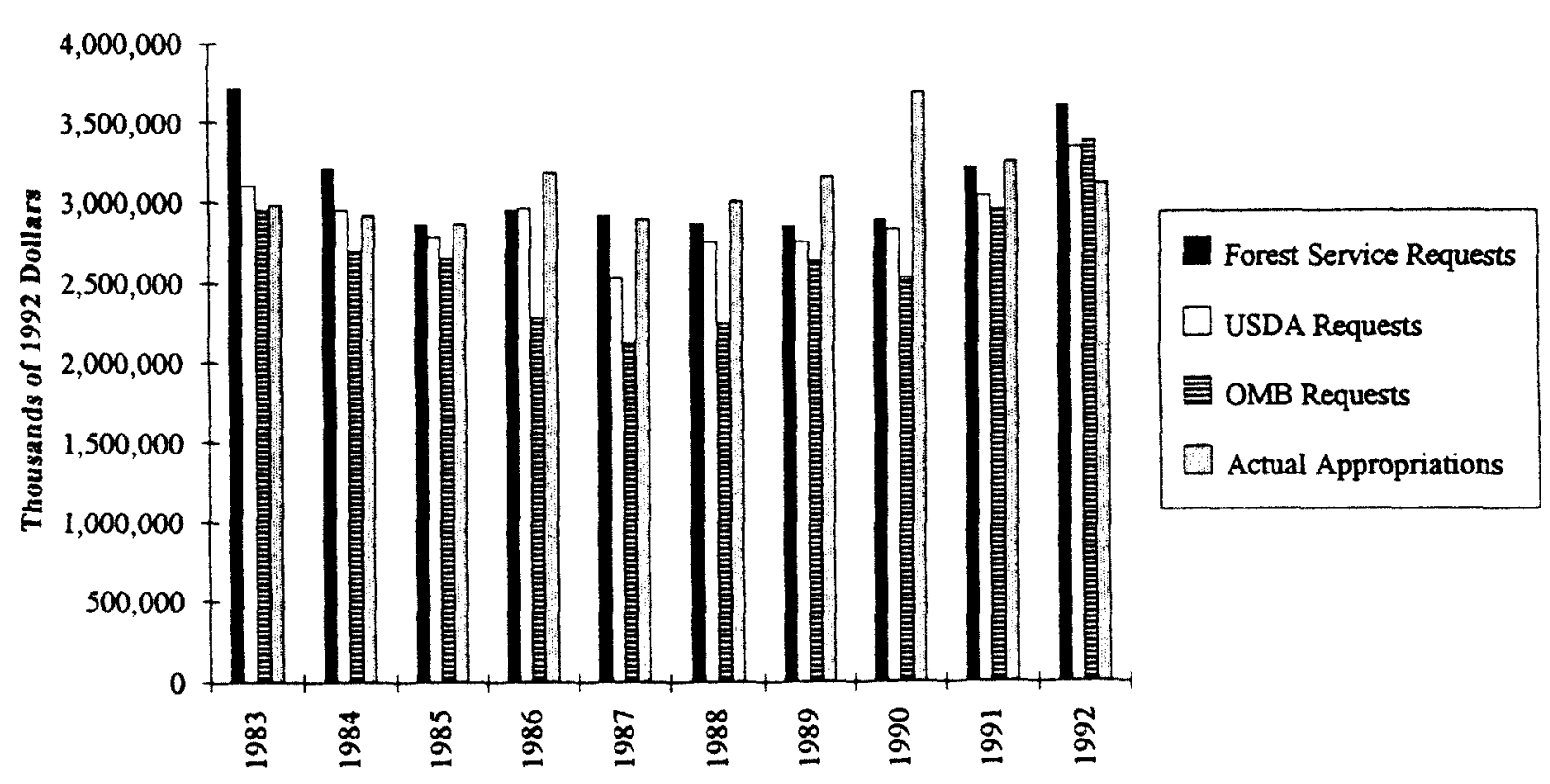




\section{The National Forest System}

Approximately one-half of the entire Forest Service budget is allocated to the National Forest System, to be used for the protection, management, and utilization of Forest Service lands. As Figure 1 shows, overall funding for the National Forest System has not changed significantly over the past decade (again, appropriations for firefighting in 1990 account for that year's large increase). Funding levels have hovered around $\$ 1.5$ billion. The requests for the National Forest System show a trend similar to that of requests for the total Forest Service budget. From 1985 to 1991, Congress consistently funded the National Forest System at levels above all three requests. In 1992, requests reached unprecedented levels, only to be met by a decrease in actual appropriations. Once again, budget requests tended to follow congressional appropriations, rather than the other way around, raising questions about how much influence these offices have on Congress's decisions about how much funding to provide.

Although overall funding for the National Forest System has not varied greatly, there have been significant changes within its different components. From the 15 line items that comprise the National Forest System, appropriations for six categories have been charted in Figure 3. These line items were selected over others either because of their significance as commodity or non-commodity management programs or because of the marked increase or decrease in funding that has occurred.

\section{Figure 3 \\ Congressional Appropriations-Six Line Items from the National Forest System}

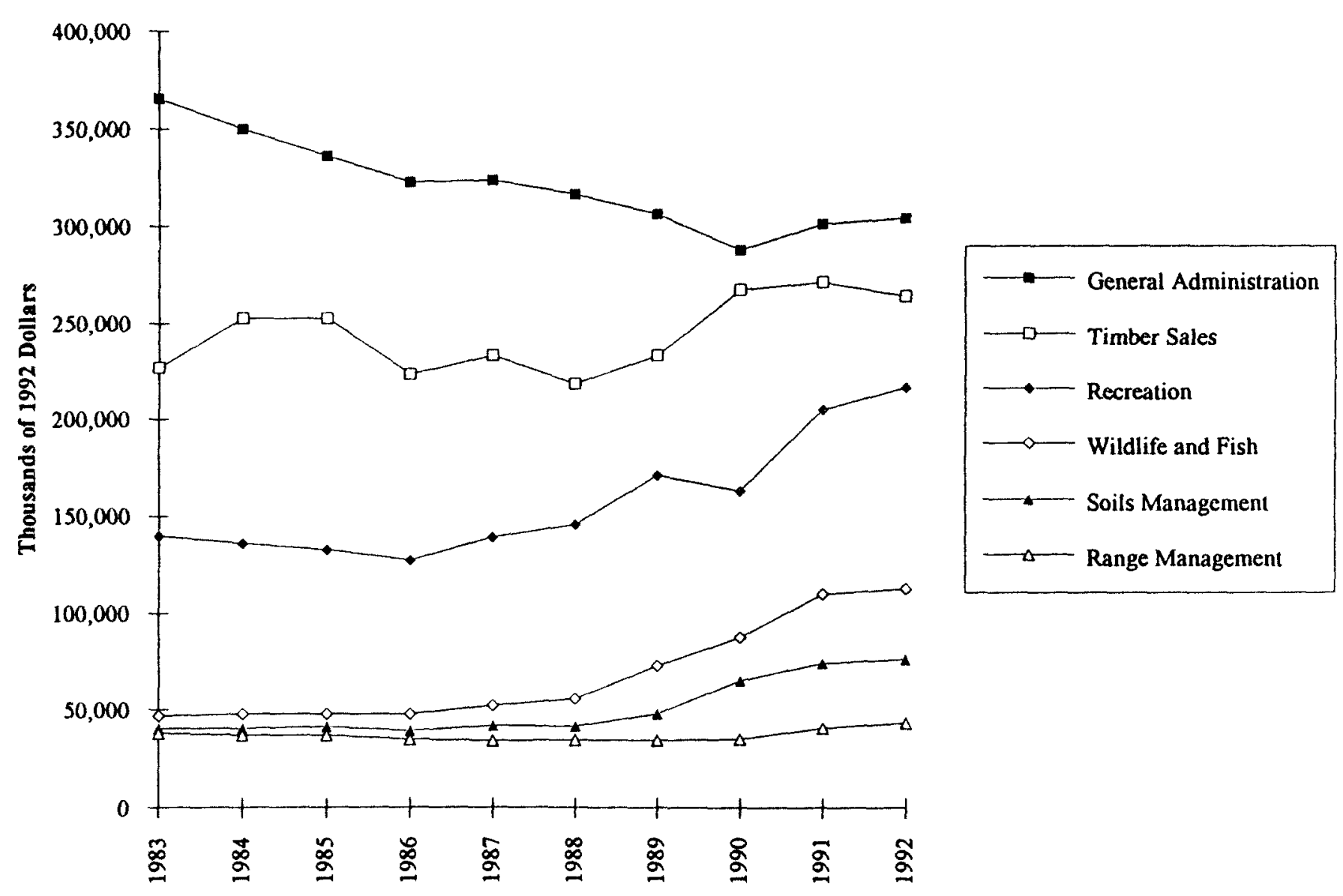


Also, excepting General Administration, five line items represent the five traditional multiple uses of the National Forests: timber, recreation, wildlife, water (included in "Soils Management"), and range. It should be noted here that these line items are only part of the entire National Forest System budget. Thus, the collective trends of the individual line items studied here may not reflect trends in total budget requests and appropriations.

General Administration has had the highest level of funding of all 15 components of the National Forest System. However, it also has experienced the largest decrease in appropriations, dropping from \$365 million in 1983 to \$304 million in 1992. Timber Sales, in contrast, has shown an overall increase, rising from $\$ 227$ million in 1983 to $\$ 264$ million in 1992. Recreation Management has shown an even greater increase (54\%), growing from \$140 million in 1983 to \$216 million in 1992. Perhaps most dramatic, however, has been the $102 \%$ increase in the Wildlife and Fish Management budget. In fact, that doubling occurred in just five years, increasing from $\$ 56$ million in 1988 to $\$ 113$ million in 1992 . Also increasing significantly were appropriations for Soils Management, showing a 90\% increase, from $\$ 40$ million in 1983 to $\$ 76$ million in 1992. Funding for Range Management did not change significantly during the 1980 s.

\section{Comparison with Requests and Discussion of Funding Levels}

\section{General Administration}

General Administration provides indirect support costs for the National Forest System, Research, and State and Private Forestry programs. These costs cannot be identified readily with specific projects or programs (United States Department of Agriculture, Forest Service, 1981-1992). Comparing the three different agency requests with actual appropriations for General Administration (Figure 4a), a fairly close relationship is found between all three requests and final funding levels. Apparently, the Forest Service worked hard over the decade to streamline the number of personnel

\section{Figure 4a}

General Administration Budget Requests and Appropriations

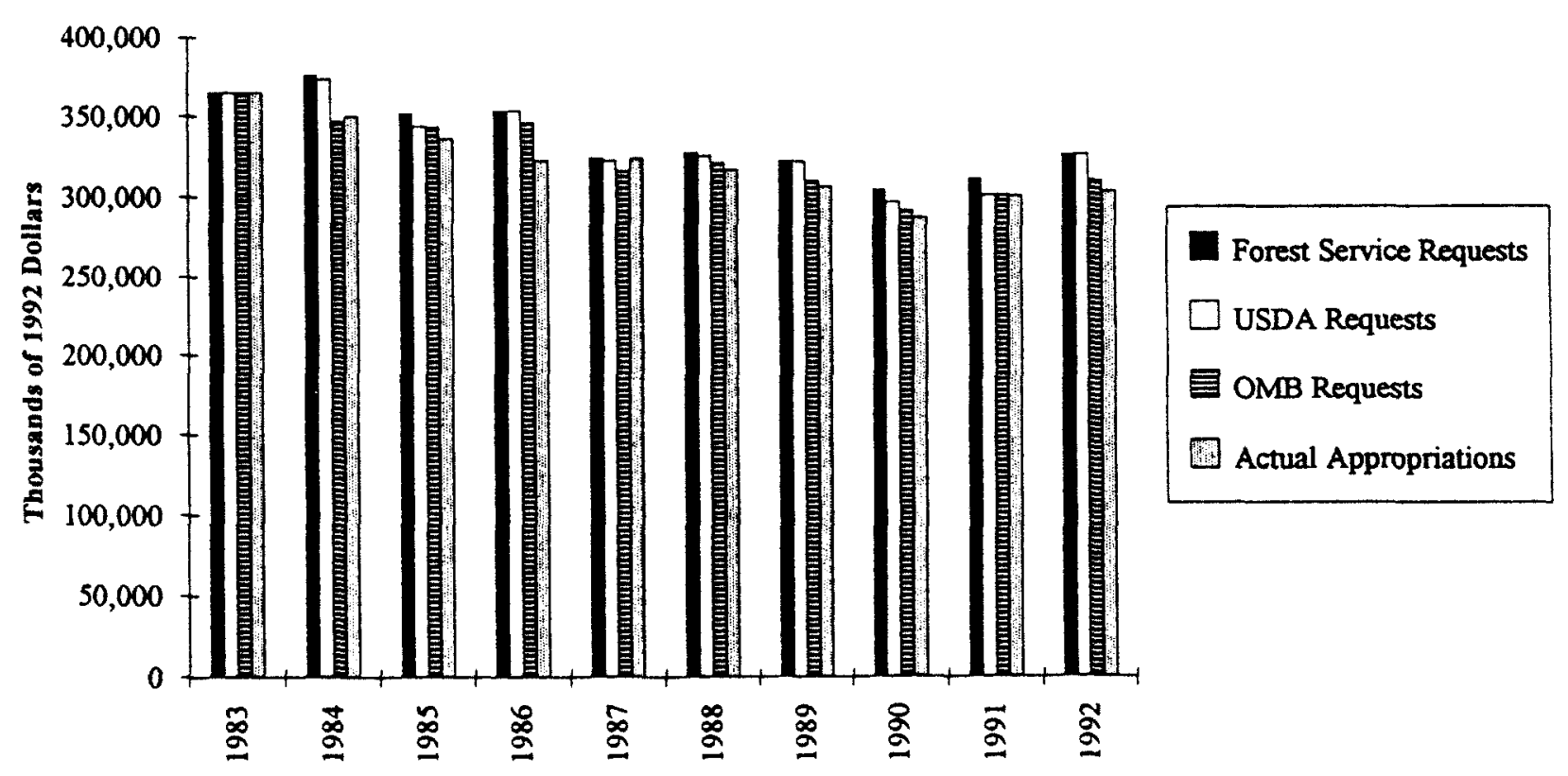


and procedures that are accomplished in General Administration (United States Department of Agriculture, Forest Service, 1981-1992), resulting in similar requests from all offices and a significant decrease in the final appropriations amount. Once again, it seems that Congress has led the way for these reductions, for in almost every year appropriations were lower than any of the requests.

It should be noted that from 1983 to 1992, there was no transfer of tasks from the General Administration line item to other line items in the National Forest System. The reduction in appropriations has occurred because of efforts to tighten efficiency in administrative tasks (United States Department of Agriculture, Forest Service, 19811992). Therefore, increased funding for the line items representing the five traditional multiple uses are not connected to the decrease in General Administration appropriations. The trends are independent of one another.

\section{Timber Sales}

Any relationship between appropriations for Timber Sales and budget requests (Figure 4b) is hard to decipher. In general, from 1983-1989 (except 1987), congressional appropriations were less than any of the requests. However, in 1990 and 1991, Congress raised the funding level more than either OMB or USDA had requested. In 1991, Forest Service requests jumped to unprecedented levels, far above the other requests and final appropriations. The Forest Service maintained that high level in 1992, and both the USDA and OMB raised their requests. However, in 1992, Congress was not persuaded by requests to raise funding levels; appropriations remained at 1990 and 1991 amounts. Still, funding and request levels for 1990-1992 were some of the highest in the past ten years.

The budget coordinator for the national Timber Sales Program identifies an increase in the amount of detail and time needed to complete sales preparation activities as the main reason for the program's increased costs (Reed, 1993). Because of rising concern for the environmental effects of timber sales, more money must be spent to account adequately for threatened and endangered species, the protection of archaeological

\section{Figure 4b}

\section{Timber Sales Budget Requests and Appropriations}

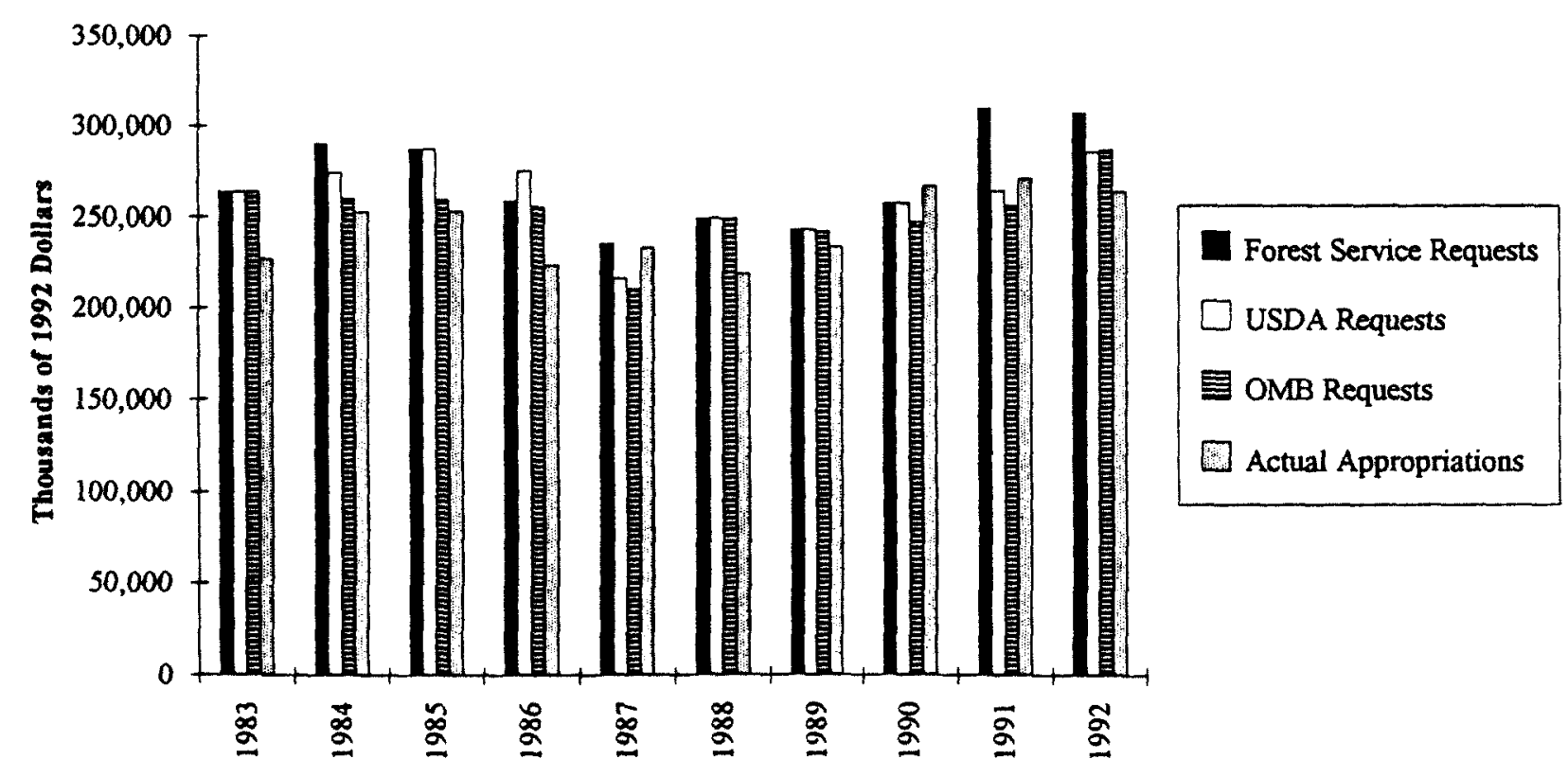


sites, "visual" management, and other forest resources. Many of these additional costs can be attributed to the integration of a new Ecosystem Management philosophy. In addition, lawsuits that hold up sales in court can increase costs either by requiring further studies or by revoking sales that were prepared previously. Certainly, increased funding has not translated into increased timber output, as the volume of timber sold on National Forest land has plummeted since the late 1980s (Farnham \& Mohai, 1995). Rather, increased requirements for sales preparation and coordination with other resource programs have driven up funding levels (Reed, 1993).

\section{Recreation Management}

Recreation requests from the Forest Service, USDA, and OMB have followed a curious trend (Figure 4c). From 1983 to 1986, requests and appropriations were matched fairly closely. However, in 1987, OMB suddenly cut the Recreation budget request in half. In the same year, the Forest Service and USDA increased their requests slightly. OMB's dramatic decrease had little effect on Congress's appropriations, and actual funding increased in accordance with Forest Service and USDA requests. Between 1988 and 1990, OMB requests continued to be far below USDA and Forest Service requests, but Congress still increased its funding (except in 1990, when there was a slight decrease). However, in 1991, OMB raised its request above both the Forest Service and USDA estimates, and Congress increased funding from $\$ 162$ million to $\$ 205$ million. Finally, in 1992, OMB's request shot far above the other requests. Congress responded with only a mild increase, which matched the Forest Service's request more closely than it matched OMB's. It is difficult to explain OMB's erratic behavior. However, it is important to note Congress's refusal to follow the President's lead in dramatic cuts for Recreation Management in the middle of the decade.

The recent increase in funding for Recreation Management results from several factors, according to Recreation Budget Coordinator Gerry Farmer. Most of the increase is in response to the backlog of maintenance work needed to upgrade recreation facilities in the National Forests. The need for additional funding has been brought to the

\section{Figure 4c}

\section{Recreation Management Budget Requests and Appropriations}

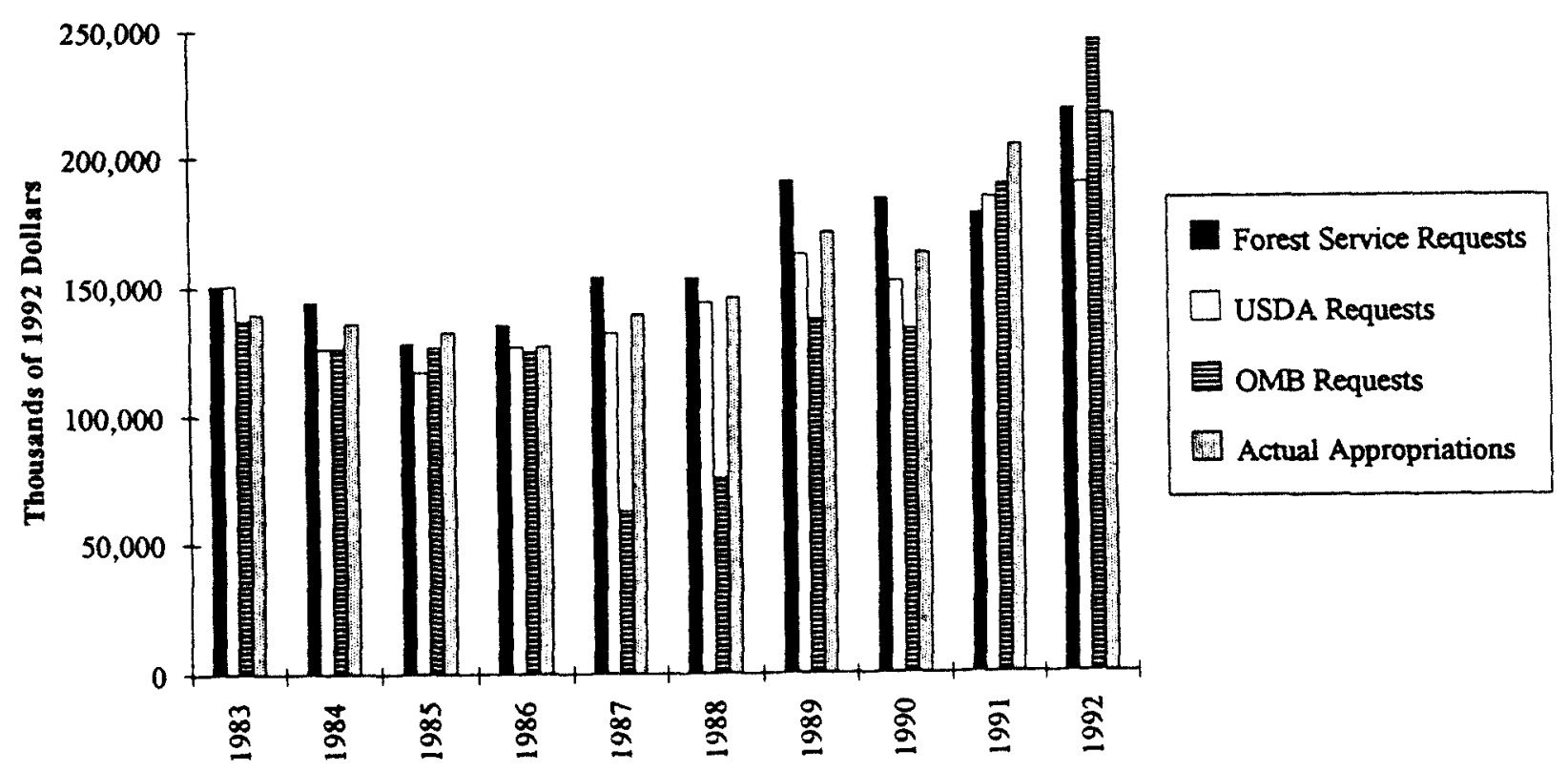


attention of Congress by the publication of several GAO reports describing the deteriorated condition of recreational facilities in the forests. In addition, user groups such as those in the National Recreation Coalition have increased their efforts to lobby for funds for the recreation program (Farmer, 1993). National environmental groups also have intensified their attempts to raise appropriation levels for Wilderness Management, a component of the Recreation Management line item. (Funding for Wilderness Management doubled in five years.)

Congress also may be responding to the increased recreation use that has been documented by the rising number of Recreation Visitor Days on National Forest lands (Farnham, Taylor, \& Callaway, 1995). However, if the appropriations increase is only to relieve the pressure of backlog maintenance, it will be important to see whether future funding remains at these high levels or falls back to past levels. The question remains whether the change in the past five years of our data is a permanent shift in congressional priorities.

\section{Wildlife and Fish Management}

Appropriations for Wildlife and Fish Management generally have followed most closely Forest Service requests for the past decade (Figure 4d). As with Recreation, requests and appropriations were fairly equal between 1983 and 1986, but in 1987 the Forest Service began to increase its request. Congress obliged, and then proceeded to raise funding levels beyond any of the requests from 1990 to 1992, topping off in 1992 at $\$ 113$ million. Two of the beneficiaries of this increase were the Forest Service's Threatened, Endangered, and Sensitive Species program and their Anadromous Fish Management program. The funding for both programs individually (within the Wildlife and Fish line item) in 1992 increased more than five times the appropriation levels in 1988.

Bob Nelson, Director of the Wildlife and Fish Management Division of the Forest Service since 1985, attributes the increased appropriations to heightened relations

\section{Figure 4d}

Wildlife and Fish Budget Requests and Appropriations

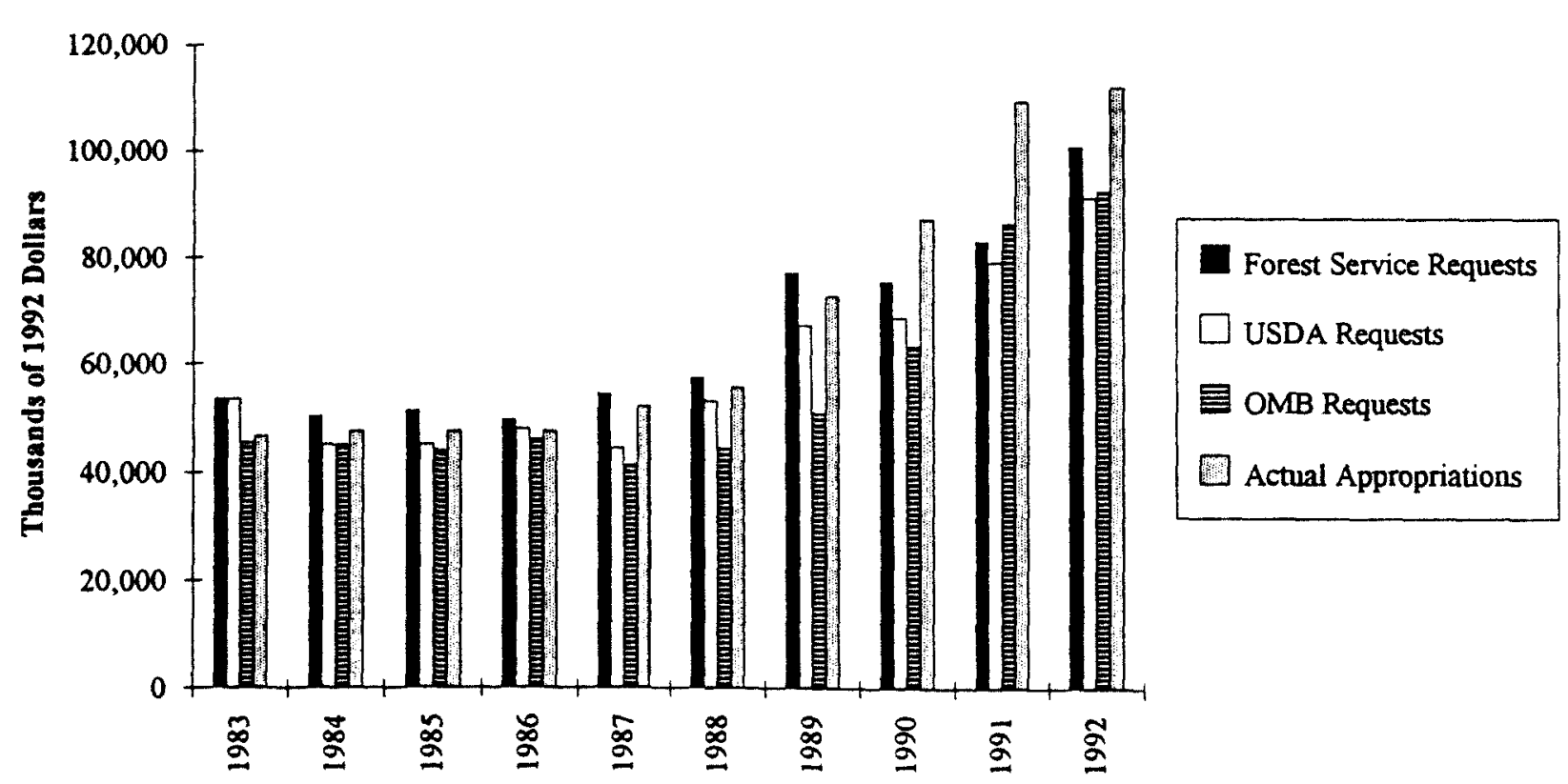


with both hunting/fishing groups and environmental organizations. A flurry of new programs was offered in the late 1980s (Farnham, Taylor, \& Callaway, 1995), and subsequent clarification of the programs' descriptions and goals allowed Congress to understand better how funds were to be employed. In addition to these "marketing techniques" used to sell the new programs to Congress, the partnerships that the division had worked out through Challenge Cost-Share programs sparked the activity of lobbying groups on Capitol Hill (Farnham, Taylor, \& Callaway, 1995). The combination of well-described programs and the lobbying of interest groups influenced Congress to increase funding levels for Wildlife and Fish Management (Nelson, 1993). This type of direct influence on the planning process by interest groups is discussed at length by Klay and McElveen (1991).

\section{Soils Management}

In Soils Management (Figure 4e), between 1983 and 1989, Congress apparently found a middle road in appropriation levels between the different requests. From 1990 to 1992, Congress increased funding by more than 50\% above 1989 levels and allocated more money to Soils Management than any of the agencies had requested. Once again, as with Wildlife and Fish Management, it seems that these increases were not spurred by any specific requests. Rather, requests increased after Congress had indicated a willingness to raise funding levels.

One reason for these increases is that a number of National Forests are preparing to update their forest plans, as they are required to do every ten years by NFMA. In addition, however, recent inventories are more detailed than they have been in the past because of an emphasis on integrating inventories of soils, wildlife, and vegetation. The detail required for such integration has increased significantly the time and cost of field work and analysis (Rasmusson, 1993). Apparently, Congress was convinced that such changes were worth the money. It is important to note that this shift toward a more ecological perspective of management matches the changes that are occurring in the way Timber Sales are prepared, as would be expected.

\section{Figure 4e}

\section{Soils Management Budget Requests and Appropriations}

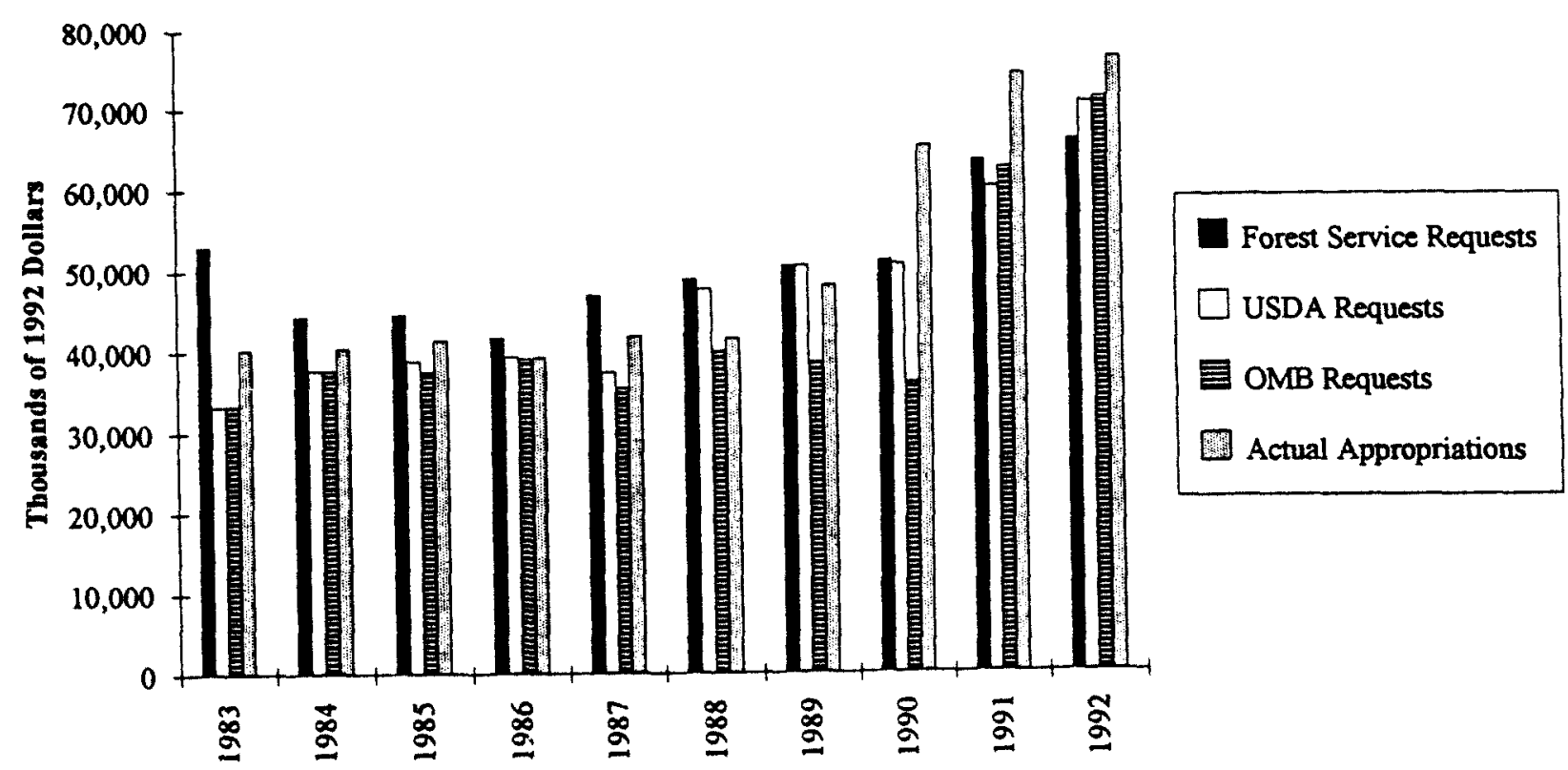




\section{Range Management}

Funding for Range Management (Figure 4f) has remained fairly constant, fluctuating between $\$ 35$ million and $\$ 43$ million over the past decade. Request levels also have been steady, except for OMB requests for 1988-1990, which were significantly lower. By 1992, however, all three requests and appropriations had reached their highest level of funding in the past decade.

\section{Figure 4f \\ Range Management Budget Requests and Appropriations}

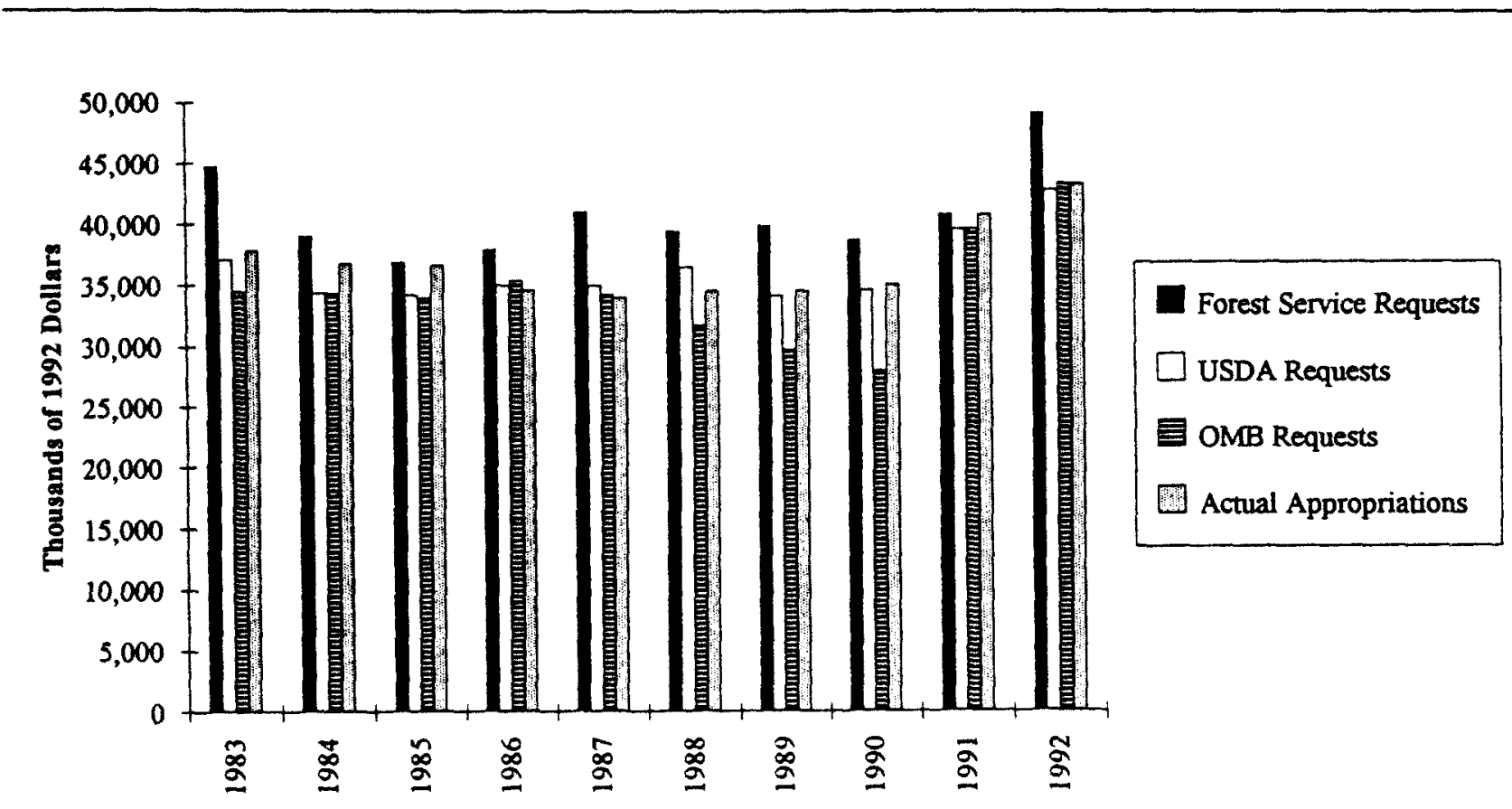

\section{Interpreting the Forest Service Requests}

Because the Forest Service requests for these important line items often are higher than appropriations over the ten-year period since 1983, it could be inferred that the Forest Service is placing a higher priority on these programs than is Congress. Consequently, one would believe that Congress has restricted Forest Service activities by not funding the programs at the requested levels. However, as evidenced by the request data, it is common for the Forest Service to request more than it receives; that fact likely is considered to be part of the political process of budget requests, as stated above. Thus, the simple observation that the Forest Service normally has requested more funds for a program or activity than Congress has provided does not necessarily indicate a higher priority on the part of the agency.

Rather, a more useful method for assessing the priorities of the Forest Service and of Congress is to look at the percentage of the National Forest System budget that each of the above line items represents. This information is summarized in Table 1. Percentages for fiscal years 1983 and 1992 and the change that occurred over that period are listed. As shown, the percentage of total funds allocated to these five line items grew from $31.6 \%$ to $45.8 \%$. The corresponding increase in the Forest Service request is smaller, from $35.8 \%$ to $42.2 \%$. Congress moved from placing a lower collective priority on the five traditional multiple uses in 1983 to a higher priority in 1992 than the Forest Service placed on them. 
In addition, most individual line items showed increased priority from 1983 to 1992. In both appropriations and Forest Service requests, Timber Sales increased in priority, rising from $14.6 \%$ to $17 \%$ in appropriations and from $16.7 \%$ to $17.5 \%$ in requests. Although Congress increased its priority for the timber program, it still did not quite reach the levels of funding requested by the Forest Service. The percentages of funds for Recreation, Wildlife and Fish, and Soils Management show a different trend. While congressional priorities for these programs were less than those of the Forest Service in 1983, Congress increased funding, such that by 1992 they had surpassed the Forest Service priorities. This shift for Congress is reflected in percentage point changes for the three line items-Recreation $(+4.9 \%)$, Wildlife and Fish $(+4.2 \%)$, and Soils (+2.3\%) - as compared to changes in Forest Service priorities for those same line items $-+2.9 \%,+2.4 \%$, and $+0.4 \%$, respectively. Range Management showed little or no change over the ten-year period.

Thus, Congress now is allocating a higher total percentage than the Forest Service has requested for these five traditional uses collectively. In addition, the individual percentages over the past decade show that Congress is changing its view of how the Forest Service should manage its lands more quickly than the Forest Service is changing itself. Through appropriations, Congress has indicated its increased priority on Recreation, Wildlife and Fish, and Soils Management. The Forest Service, while also showing increased priority in these line items, has fallen behind the percentages provided by Congress. In short, Congress seems to be directing the Forest Service through appropriations more than it is responding to Forest Service requests.

\section{Table 1}

Budget Priorities of Congress and the Forest Service (USFS) for National Forest System Line Items

\begin{tabular}{lcccccc}
\hline & \multicolumn{3}{c}{ Congress } & \multicolumn{3}{c}{ USFS Request } \\
$\begin{array}{l}\text { Line Item } \\
\text { Timber }\end{array}$ & $\mathbf{1 9 8 3}$ & $\mathbf{1 9 9 2}$ & Change & $\mathbf{1 9 8 3}$ & $\mathbf{1 9 9 2}$ & Change \\
$\begin{array}{l}\text { Sales } \\
\begin{array}{l}\text { Recreation } \\
\text { Management }\end{array}\end{array}$ & $14.6 \%$ & $17.0 \%$ & $2.4 \%$ & $16.7 \%$ & $17.5 \%$ & $0.8 \%$ \\
$\begin{array}{l}\text { Wildlife and Fish } \\
\text { Management }\end{array}$ & 3.0 & 13.9 & 4.9 & 9.5 & 12.4 & 2.9 \\
$\begin{array}{l}\text { Soils } \\
\text { Management }\end{array}$ & 2.6 & 4.9 & 2.3 & 3.4 & 3.7 & 0.3 \\
$\begin{array}{l}\text { Range } \\
\text { Management }\end{array}$ & 2.4 & 2.8 & 0.4 & 2.8 & 2.8 & 0.0 \\
Total & 31.6 & 45.8 & 14.2 & 35.8 & 42.2 & 6.4
\end{tabular}

Note:

Numbers are percentage of the total National Forest System budget.

\section{Summary and Conclusions}

In summary, these programs-Timber, Recreation, Wildlife and Fish, Soils Management, and Range Management-represent important components in the multiple-use mandate of the Forest Service. Although overall funding for the National 
Forest System has not changed over the past decade, reduced appropriations for General Administration has offset increases in funding for the line items representing the five traditional uses of the national forests. An often-heard criticism of the Forest Service is in reference to its unequal treatment of non-commodity programs such as Recreation and Wildlife Management, by comparison with its Timber Sales program. However, it is apparent from the changes in request levels and in the percentage of funds requested that the Forest Service slowly is shifting its priorities toward giving more importance to non-commodity programs. In some specific cases, such as the Threatened, Endangered, and Sensitive Species program within the Wildlife and Fish Management line item, the increase in requests for funds has been most dramatic. (Current congressional activities regarding the Endangered Species Act very likely may have an effect on this trend.)

The trends in actual congressional appropriations suggest that Congress was targeting specifically these non-commodity programs for expansion by supplying them with increased funding. Congressional priorities, as shown in Table 1, have grown much more quickly than have those of the Forest Service for Recreation, Wildlife and Fish, and Soils Management. Appropriations for Timber Sales also have increased, but not because the timber output from the national forests is growing; rather, as cited above, the increase in funds results from an attempt to address the broadening concerns for other values affected by timber harvests.

Certainly, then, change is occurring in the Forest Service. But the source of this change is not entirely clear. When examining requests and appropriations, it is important to address the issue of who is leading whom. Because of the apparent lead that Congress takes in determining funding, the budget data suggest that Congress is attempting to push the Forest Service toward a particular balance among the five traditional multiple uses. The logical conclusion is that Congress has been the impetus for the changes that are occurring in Forest Service appropriations.

The implication of directing the Forest Service through budgetary allocations is that, as mentioned above, a breakdown has occurred somewhere in the overall planning process. It is evident from these trends that there was a lack of integration between management planning and the budget process. However, it is important to recognize that with the release of the 1990 RPA program and with the number of completed Forest plans growing continually, it is apparent that the Forest Service is attempting to communicate its management direction and objectives to Congress more effectively. The appropriations process must work in concert with the planning process; otherwise, all of the time and money invested in the RPA documents and forest plans will have been wasted.

There is little reason to believe that these changes in Forest Service funding are temporary. Indeed, the shift in priorities for the Forest Service seems to be part of a fundamental change in philosophy. In particular, because the 1990 RPA and the completed forest plans generally are placing increased emphasis on non-commodity concerns, it is possible that appropriation levels for line items like Recreation, Wildlife and Fish, and Soils Management will continue to grow. With recent controversies over timber sales and range management, it is difficult to predict how funding for these line items will be affected. However, it is likely that these programs also will need more money as the complexity of management concerns increases. The present changes documented in this study may be precursors to a more permanent change in Forest Service activities. 
Timothy J. Farnham is communications coordinator for the Society of American Foresters (SAF), in Bethesda, Maryland. With SAF, Mr. Farnham is responsible for forestry outreach programs and internal organization communications. He received his M.S. in natural resources policy from the School of Natural Resources and Environment at the University of Michigan in Ann Arbor, and his B.A. from Williams College in Williamstown, Massachusetts. Research for this article was conducted while at the University of Michigan.

\section{References}

Brown, G., \& Harris, C. (1992). The U.S. Forest Service: Toward the new resource management paradigm? Society and Natural Resources, 5, 231-245.

Farmer, G. (1993, November). Personal communication with Gerry Farmer, Budget Coordinator, Recreation Management, United States Department of Agriculture, Forest Service. Washington DC.

Famham, T., \& Mohai, P. (1995). National Forest timber management over the past decade: A change in emphasis for the Forest Service? Policy Studies Journal, 23 (2), 268-280.

Famham, T., Taylor, C., \& Callaway, W. (1995). A shift in values: Non-commodity resource management and the Forest Service. Policy Studies Journal, 23 (2), 281-295.

Gremillion, L., McKenny, J. L., \& Pyburn, P. J. (1980). Program planning in the national forest system. Public Administration Review, 40 (3), 226-230.

Ibbotson Associates. (1992). SBBI: Stocks, bonds, bills, and inflation index. 1992 yearbook. Chicago, IL: Author.

Jones, E. S., \& Mohai, P. (1995). Is the Forest Service keeping up with the times? Interest group and forestry school perceptions of post-NFMA change in the United States Forest Service. Policy Studies Journal, 23 (2), 351-371.

Jones, E. S., \& Taylor, C. (1995). Litigating agency change: The impact of the courts and administrative appeals process on the Forest Service. Policy Studies Journal, 23 (2), 310-336.

Klay, W., \& McElveen, J. (1991). Planning as a vehicle for policy formulation and accommodation in an evolving subgovernment. Policy Studies Journal, 19 (3-4), 527-533.

McCarthy, C., Sabatier, P., \& Loomis. J. (1991, March 21-22). Attitudinal change in the Forest Service: 1960-1990. Paper presented at the annual meeting of the Westem Political Science Association. Seattle, WA.

Mohai, P., Stillman, P., Jakes, P., \& Liggett, C. (1992). Change in the USDA Forest Service: Are we heading in the right direction? General Technical Report NC-172. St. Paul, MN: United States Department of Agriculture, Forest Service, North Central Forest Experiment Station.

Nelson, B. (1993, March 1). Personal communication with Bob Nelson, Director of Wildlife and Fish Management, United States Department of Agriculture, Forest Service. Washington DC.

Novick, D. (1973). Current practices in program budgeting. New York, NY: Crane Russal.

O'Toole, R. (1988). Reforming the Forest Service. Washington, DC: Island Press.

Rasmusson, D. (1993, March 2). Personal communication with Dean Rasmusson, Budget Coordinator, Soil, Air, and Water Operations, United States Department of Agriculture, Forest Service. Washington, DC.

Reed, M. (1993, March 2). Personal communication with Mert Reed, Budget Coordinator, Timber Sales, United States Department of Agriculture, Forest Service. Washington DC.

Sample, V. A. (1990). The impact of the federal budget process on national forest planning. Westpon, CT: Greenwood Press.

Sample, V. A. (1992). Resource planning and budgeting for national forest management. Public Administration Review, 52 (4), 339-346.

Tipple, T., \& Wellman, D. (1991). Herbert Kaufman's forest ranger thirty years later: From simplicity and homogeneity to complexity and diversity. Public Administration Review, 51 (5), 421-428.

United States Department of Agriculture, Forest Service. (1984-1992). Reports of the Forest Service FY 1983-1991. Washington, DC: Author.

United States Department of Agriculture, Forest Service. (1981-1992). Budget explanatory notes for the Committee on Appropriations FY 1983-1994. Washington, DC: Author.

United States General Accounting Office. (1992). Wilderness management: Accountability for Forest Service funds needs improvement. GAO/RCED-92-33. Washington, DC: Author. 
This document is a scanned copy of a printed document. No warranty is given about the accuracy of the copy. Users should refer to the original published version of the material. 